\title{
Important Contributions of Early Muslim Period To Medical Science. I. Basic Sciences
}

M.G. Muazzam, M.B.B.S., F.R.C. Path. and N. Muazzam, M.B.B.S. Dhaka, Bangladesh

\begin{abstract}
Scientists of the Early Muslim Period contributed greatly to the development of modern medical science. Among their contributions to the basic medical sciences, the contributions of al-Kind $\vec{i}$, al-Rāzi, 'Abdul-Latif and $I b n$ al-Nafis in anatomy, and those of al-Rāzi, 'Ali ibn 'Abbäs, Ibn Sina and Ibn al-Nafís in physiology are noteworthy. 'Abdul-Latif was the first to note that the human lower jawbone is one bone and not joined as was believed by the Greeks. Ibn al-Nafis was the first to discover the pulmonary circulation, about 300 years before the Europeans were supposed to have discovered it. The contributions in pathology and microbiology were few in the absence of microscopes and cellular pathology, yet the idea of contagiousness of certain diseases, body or natural resistance, allergic reactions, idiosyncracy, conditioned reflex and localization of external senses in the brain were put forward by the scientists of the period.

The Muslim period established the basis of modern pharmacopoeia and introduced a large number of drugs still in use.
\end{abstract}

Key words: Muslim scientists, Muslim physicians, pulmonary circulation, basic medical sciences

Medical sciences like other branches of human knowledge are the cumulative products of different nations of both the East and the West. In spite of many superstitions, the ancient Egyptians, Persians, Chinese and Indians contributed significantly to medical sciences. The rational approach to medical sciences was introduced by the Greeks in the fifth century B.C. Greek medicine was being practiced in the Eastern Roman (Byzantine) Empire encompassing most of the Middle East when the last Prophet of Islam, Muhammad, began his divine mission in Arabia (610-633 A.C.) When Islam conquered the land and the people of these areas, Muslim scientists began to translate the Greek books of science from Latin and Syriac into Arabic under the direct patronage of the Muslim Khulafa' (Caliphs) of Damascus and Baghdad. While doing so, they invited and encouraged the efforts of the non-Muslim scholars and scientists.

From the eighth century, the Muslim scholars began to contribute to the existing body of knowledge. The scientists of the early Muslim period

From Ibn Sina Laboratories, Dhaka, Bangladesh.

Reprint requests: M.G. Muazzam, M.B.B.S., F.R.C. Path, Ibn Sina Laboratories

Road No. S.A, House No. 57

Dhanmondi R/A, Dhaka, Bangladesh. did not restrict their study to Greek books but collected scientific books and materials from China, Persia, Egypt, and India and established a broadbased medical science.

Because Muslims built their medical science on the basis of Greek medicine, they named their system of medicine "Yūnānī" or Greek medicine. By the same token, modern medicine which is the direct continuation of the medical science of the Muslim period, should be renamed "Islamic medicine". However, the post-renaissance Europeans did not show the same magnanimity of Muslims, by showing proper respect to Islamic medicine on which they built the basis of modern medicine. It is only during the last hundred years that some Western scholars have come forward with recognition of achievements of the Muslim period of Middle Ages. One such scholar writes, "the Arabian physicians, whose golden age falls between the 8 th and the 13 th centuries, were also the instructors of the physicians of the West in Yūnanin (Grecian) medicine. Even as late as the 17 th century, their writings were the text books for lectures in Western universities".'

These glorious and spectacular achievements were possible due to encouragement given by the Holy Qur'an and Prophet Muhammad to acquire knowledge. It was only after the fall of Baghdad in 1285 and that of the Western Caliphate in 1492, that Muslims began to lag behind. Later with the fall of the Moghal Empire in the 19th century, the leader- 
ship of medical science was shifted again to the West. The Yūnani system continued as an indigenous system in the Indian subcontinent. Beginning in the late 19th century, unprecedented advances in all branches of science, including medicine, were achieved in the West. Beginning in the early part of the 20th century, Muslims all over the world have shown signs of re-awakening and revitalization and they are now trying to know the past achievements of their illustrious predecessors to inspire themselves.

In this paper, I shall present some of the important contributions of the early Muslim period to basic medical sciences. In a forthcoming paper, ${ }^{2}$ I shall present contributions to medical and surgical specialities.

\section{Contributions to anatomy}

Because dissection of human dead bodies was not permitted, physicians of the early Muslim period had to depend on the anatomy of Galen (130-200 A.C.). But this Greek anatomy had many mistakes because the Greeks also had limited opportunity to dissect the human body. They based their knowledge on the examination of executed criminals and soldiers killed in the battlefields. The Arab scientists soon realized that there were many mistakes in Galen's anatomy. In order to get correct knowledge of human anatomy a dissection hall was established on the bank of the river Tigris near Baghdad during the reign of alKhalifah al-Mu'tașim billāh (circa 836 A.C.). The Muslim governor of Nubia in Africa used to supply chimpanzees and apes for dissection.

A listing of some prominent scientists of the early Muslim period and their contributions to anatomy follows:

1. Yūhanna ibn Māsawīh (died 867 A.C.) was the court physician of several Caliphs of Baghdad from 780 to 857 A.C. He was in charge of the dissection hall and many anatomical and medical writings are credited to him. ${ }^{3}$ These writings can be considered the earliest attempts for systematic study of anatomy and they laid the foundation for comparative anatomy.

2. Al-Kindi (810/13-873 A.C.) was an Arab and known as "The Philosopher of the Arabs" in the West. "He advocated dissection of animals to improve the knowledge of anatomy and wrote a book on the subject, "Risālah fi "Ajsād alHayawanat" (About the Dissection of Animal Bodies), which is probably the earliest practical guide for dissection."

3. Al-Razi (841-926 A.C.) was the first to mention the double recurrent nerves, the infratrochlear branch of the nasal nerve, the trigeminal nerve, etc. ${ }^{\circ} \mathrm{It}$ is interesting to speculate how he found out these nerves without dissecting human bodies.

4. Ibn Sinā (Avicenna) (980-1037 A.C.) though dependent on Galen's book of anatomy, has the distinction of describing the position and function of the lachrymal ducts and noted the six motor muscles of the eyeball.

5. 'Abü Sahl al-Masihịi (11th Century A.C.) was a contemporary of Ibn Sina who knew how the valves of the heart function and recognized all the incoming and outgoing vessels of the heart. However, he failed to understand the pulmonary circulation. . $^{-1}$

6. 'Abdul-Latif al-Baghdadi (1162-1231 A.C.) emphasized that to know human anatomy one should study the human body instead of depending on Greek books of the past. He examined a large number of human skeletons in a graveyard near Cairo and improved his knowledge of anatomy, especially osteology. He wrote a book on anatomy, "Improved Anatomy", which is no longer available. Al-Baghdādī corrected Galen and declared for the first time that the human lower jawbone is one piece not a joined one. ${ }^{9} \mathrm{He}$ was also the first to point out that the human sacrum in adults is one piece of bone though it consists of several pieces in childhood. ${ }^{10}$

7. Ibn al-Nafis (1208-1288 A.C.) corrected some wrong ideas of Galen about the human heart. $\mathrm{He}$ declared that the human heart contains two ventricles not three as suggested by Galen. Thus, he was the first to challenge the Galenic theory, which was accepted even by Ibn Sinā. Ibn alNafis wrote in his famous book "Commentary on the Anatomy of the Canon of Aicenna", "... there are in the heart two ventricles only... Moreover, there is absolutely no opening between the two ventricles for the septum between the two ventricles is much thicker than any other, preventing the passage of any of the blood and spirit and thus their loss. Also, the statement that the septum is porous is wrong". ".

8. 'Ibrāhim al-Shadhli (14th Century A.C.) was the first to discuss the embryological origin of the eyes. He also compared the size, color, shape, and appearance of the eyes of different races, viz. Negroes, Turks, Bedouins, citydwellers, etc. This may be the earliest study on comparative anthropology.12

9. Muslim physicians were the first to recognize that the cranium (skull) is composed of eight, not seven, bones as suggested before. They also pointed out the three bones of the middle ear that are essential for hearing. ${ }^{3}$

\section{Contribution to physiology}

Some of the Muslim scientists and their contributions to physiology are listed below:

1. 'Ali ibn Sahl ibn Rabn al-Tabari (born circa 810 A.C.) in his famous book "Fardūs al-Hikmah", describes digestion as a form of decomposition 
and putrefaction. ${ }^{14}$

2. Al-Räzi (841-926 A.C.) was the first to describe the phemonenon of conditioned reflexes several centuries (almost a thousand years) before Sherington or Pavlov (1911). This reflex should thus be called Rāzi's conditioned reflex."

3. 'Ali ibn 'Abbās (died 994 A.C.) was the first to suggest the concept and presence of a capillary circulation. This was finally established by Spallanzani (1729-1799) in the 18th century, though in the 17th century Malpighi (1628-1680) demonstrated capillary circulation in frogs. ${ }^{16}$

4. Ibn Sinā (980-1037 A.C.) taught Galenic anatomy and physiology in general. However, he had some original contributions to physiology:

i) He wrote in his book "Canon of Medicine": "in the extremities the branches of the ascending artery (aorta) anastomose with the branches of the descending veins, so the blood passes from artery to vein and from vein to the artery (as Galen had pointed out) and in this way goes on circulating." Ibn Sinā used the word Dūr, which means revolution and passing round and round which is more explicit of the continuous circulation of blood." So the idea of the circulation of blood was known to Galen and Ibn Sinā but the ignorance of the pulmonary circulation led Galen to his erroneous theory of "pneuma".

ii) Ibn $\overline{\operatorname{Sin}} \bar{a}$ was the first to put forward the theory of brain localization of external senses, viz. sight, hearing, touch, taste, and smell.

iii) Ibn Sina stated that digestion of food commences with the exudation of humidity in the mouth which is true especially for the carbohydrates. ${ }^{18}$

5. 'Abū Sahl al-Masihịi (11th Century) stated that food is absorbed to a far greater degree from the intestine than from the stomach. Muslim physicians pointed out the presence of mesenteric veins (masariqa) with minute pores through which food is absorbed, a fact accepted in modern physiology. ${ }^{19}$

6. Ibn Zuhr (c. 1094-1162) was the first to call attention to the fact that no organ can perform its function properly without the aid of another (organ). ${ }^{20}$ Further, in opposition to Galen he assigned sensibility to the teeth and the bones."

7. Ibn al-Nafis (1208-1288 A.C.) was the first to discover the pulmonary circulation, 300 years before Europeans recognized it. ${ }^{22}$ He contributed a clear conception of the circulation of the blood three centuries before the Portugese Servetus (1509-1553 A.C.) who is credited with this discovery. ${ }^{23}$ The presentation of the lung circulation given by Servetus in his book "Christianismi restitution" resembles that of Ibn-al-Nafis so strongly, that one can hardly reject a direct in-

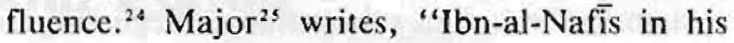
commentary on the anatomy by Avicenna, described the lesser, or pulmonary, circulation more than two centuries before either Servetus or Colombo"' (1516-1599).

The manuscript of Ibn al-Nafis was discovered in Beirut and published in $1936 .{ }^{26}$ One wonders why the remarkable findings of Ibn al-Nafīs remained unknown to the West for such a long time. Coppola ${ }^{27}$ has given an account of how the findings of al-Nafis reached Padua University where the European workers studied. He described how the Arab knowledge went to southern Europe through the "medical attaches" of Western embassies and reached Padua where the early European workers, including Harvey, studied. ${ }^{28}$ In this context it should be pointed out that "Harvey committed a grave injustice in claiming the whole credit of the discovery of blood circulation to himself. One wonders if there was anything new in the observations which Harvey made in his famous publication 'De motu cordia' in 1628." "We now know that 'Abu Sahl (11th century) described the functions of the cardiac valves, that the pulmonary circulation was discovered by Ibn alNafis, that Fabricius (1574) discovered the one-way valves of the vein, and that Sapri (16th Century) described the function of the valves in the vein. It is clear that Harvey only collected the data of his predecessors. Indeed, he declared, "I have never succeeded in tracing any connection between the arteries and veins by a direct anastomosis of their orifices; neither in the liver, spleen, lungs, kidneys or any viscus. I can therefore, boldly claim that there is neither an anastomosis between the portal vein and the vena cava, nor between the hepatic arteries and the hepatic veins." 30 So Harvey ruled out the existance of capillary system, accepted the wrong Galenic concept, and thought that blood from the minute branches of the arteries oozes out through their thin walls into the veins. Thus, Harvey really failed to discover the circulation of blood. His mistakes were corrected by Malpighi (1628-1680) in 1661 , when he demonstrated capillary anastomosis in frogs, and by Spallanzani (18th Century) in 1771, when he showed capillaries in developing chick embryo, a warm-blooded animal. ${ }^{31}$

\section{Contributions to pathology and microbiology}

Since the miscroscope was not discovered until 1632 , and bacteria not until 1880 , cellular pathology and microbiology were unknown to the scientists of the Middle Ages. However, many of them suggested the presence of invisible microbes and described many pathological processes.

1. Yühannā ibn Māsawìh (780-857) wrote a book on general pathology "Kitāb al-Kamāl wa al- 
Tamam". Some of its fragments are still available. ${ }^{32}$

2. Al-Kindi $(810 / 13-873)$ was the first to suggest contagiousness of certain diseases and suggested purification of air by smoke, though the contagion remained unknown to him."s

3. 'Ali ibn Sahl ibn Rabn al-Tabari (810-850 A.C.)

i) He was the first to point out that disease is cured by the inherent resistance of the body and not by drugs. The duty of the physician is to help the natural procssess. ${ }^{34}$

ii) $\mathrm{He}$ also pointed out personal idiosyncracy against certain drugs.

iii) 'Ali ibn Sahl al-Tabari discussed both general and special pathology of the whole body in the fourth part of his famous book, "Fardūs al-Hikmah." He also advised physicians to find out the basic cause (etiology) of the disease before starting treatment.

iv) 'Alīi ibn Sahl al-Tabari advised the exercise of "care" in regards to "food" during epidemics. This was a remarkable observation, since no bacteria were known at that age. He further emphasized the maintainence of proper nutrition of the patient during treatment, an idea almost modern. ${ }^{3 s}$

v) He was the first to notice edema of abdomen and the lower limbs in cirrhosis of the liver.

4. AJ-Rāzí (841-926 A.C.)

i) Al-Rāzi is famous for his classical monograph on smallpox and measles, "Kitāb al-Judari wa al-Hașbah (De variolis et morbilis, De peste, De pesti-lentia)," the oldest description of variola and the masterpiece of Muslim medicine. ${ }^{36}$

ii) Al-Räzi was the first to describe the hay fever type of allergic manifestation during the blooming of the rose gardens every spring. This is a clear description of spring catarrh due to pollen. ${ }^{37}$

iii) Al-Rãzi was the first to describe intraventricular hydrocephalus. ${ }^{\text {" }}$

iv) Al-Rāzi was the first to use laboratory animals in medical research. He was the first to introduce mercurial ointment but before using it clinically, he tested it by giving it to apes. Thus he should be regarded as the pioneer of animal experimentation in medical research.

5. 'Ali ibn 'Abbās (died 994 A.C.) was the first to mention aneurysm of the arteries as a disease. ${ }^{39}$

6. Ibn Sinā (980-1037 A.C.)

i) Ibn Sina gave the best clinical description of meningitis and differentiated it from meningism due to acute infection. ${ }^{40}$

ii) lbn Sina was the first to describe two types of racial paralysis; central and peripheral.

iii) $\mathrm{He}$ gave the most modern classification of jaundice; obstructive, hemolytic and toxic. ${ }^{41}$

iv) Ibn Sinä differentiated pleurisy from mediastinitis. ${ }^{42}$

v) Ibn Sinā was the first to declare pulmonary tuberculosis and venereal diseases as contagious.

vi) $\mathrm{Ibn} \operatorname{Sin} \bar{a}$ in his general pathology and therapeutics distinguishes among other matters, fifteen kinds of pain. ${ }^{43}$

7. Ibn Zuhr (1094-1162 A.C.)

i) He discussed carcinoma of the esophagus and the stomach in great detail. ${ }^{4+}$

ii) He was the first to identify the itch mite (Acarus scabei) as the causative organism of scabies. He described its physical structure for the first time. Thus, he is the world's second parasitologist after Alexander of Tralles (6th century) who first described intestinal worms. ${ }^{\text {is }}$ Ahmad al-Ṭabari (c. 970 A.C.) is also believed to have described the itch-mite and pointed out that it can be removed by the needle point." If this is correct then the honor should go to al-Tabari instead of Ibn Zuhr.

iii) $\mathrm{He}$ performed experimental operations on lower animals ${ }^{47}$ and thus he is probably the second after al-Rāzi to carry on experimental research.

iv) Ibn Zuhr noticed the bad influence of polluted air of swamps on health long before the discovery of microorganisms.

v) In a chapter, "Special Pathology," of his book, Ibn Zuhr mentions pericarditis, pericardial exudation, mediastinitis, growths in the stomach, salivary concretions (stones) under the tongue, quinsy (tonsillar abscess) etc. ${ }^{48}$

8. Ibn Rushd (1126-1196 A.C.) was the first to notice that a person does not suffer from smallpox twice in his life, ${ }^{49}$ long before Jenner noticed this type of immunity in 1796. Thus ibn Rushd should be regarded as the "Father of Immunology".

9. Müsā ibn Maymūn (1134-1204 A.C.) realized that piles (hemorrhoids) are caused by constipation and indigestion for which he prescribed light diet and plenty of vegetables, in his book, "Maqālah fī al-Bawāsìr". so

10. Ibn Khätimah (1323-1369 A.C.) and ibn alKhatib (1313-1374 A.C.) were contemporary in the Western Khiläfah.

i) They were the first to describe independently the clinical picture of plague from their personal observations during an epidemic of plague in Spain. ${ }^{31}$

ii) They declared for the first time that plague was a contagious disease.

iii) Ibn al-Khatib was the first to describe the two 
types of plague, bubonic and pneumonic."

11. Hajji Pāshā (died 1417 A.C.) was the first to describe the symptoms of lobar pneumonia which are still found to be correct. ${ }^{\text {s3 }}$

12. Baha'-ul-Dawlah (died 1507 A.C.) was the first to describe whooping cough."s

\section{Contributions to pharmacology.}

Physicians of the early Muslim period contributed heavily to pharmacology and materia medica after the initial contributions of Dioscorbides. The present day pharmacopoeia is largely based on the Arab system.

1. Al-Kindi (810/13-873 A.C.) wrote a book on pharmacology and the effects of drugs.

2. Yūhannā ibn Sarafyūn (died 930 A.C.) wrote a materia medica which was used in Europe up to the 18th century. The modern European pharmacopoeias are largely based on weights and measures used by the Arabs."s

3. Al-Räzi (841-926 A.C.)

i) Introduced emetics to vomit out poisonous foods and drinks.

ii) Al-Rāzi was the first to introduce external use of arsenic, mercurial ointment and copper sulphate. ${ }^{.6}$

iii) Al-Rāzi rejected purgatives" ${ }^{\text {st }}$ and preferred diet regulation.

iv Al-Rāzi was the first to use cold water in treating Typhoid fever. ${ }^{s b}$

4. 'Abü Manșur Muwaffaq (10th century) is the author of a famous book of pharmacology "Kitāb al-'Anbā' 'an Haqā'iq al-'Adwiyah," which contained the names of 585 drugs of Greek, Syriac, Arab, and Persian origin. Among them 466 were vegetables, 45 were minerals, and 44 were biological products. ${ }^{58}$

5. Ibn al-Wāfid (997-1078 A.C.) advised physicians to study the actions of different drugs before use and wrote a book on his own experiments, "Kitāb al-'Adwiyah al-Mufradāt.",'s

6. Mâsawiyyah al-Mārdini (925-1015 A.C.) is the author of "Grabadin," which made Arabic pharmacy familiar in Europe through hundreds of editions. It remained the standard textbook of pharmacy in the West for centuries. He also wrote books on purgatives and emetics. ${ }^{60}$

7. 'Abū al-Qāsim (936-1013 A.C.) described interesting methods of preparing drugs by sublimation and distillation. ${ }^{\circ 1}$

8. Al-Biruni (973-1050 A.C.) in his famous book, "Kitāb al-Saydalah," compiled all the medicines used in his time along with the methods of their preparation. He included names in different languages so that a pharmacist could identify a medicinal herb if he knew any of the then important languages, viz. Arabic, Greek, Syriac, Persian, Hindi, Sighzi, Jabubi, Tirmizi, Khwarizmi, etc. ${ }^{62}$ His compilation was the first of its kind which contained all the knowledge of pharmacology and materia medica from the preChrist period to his own time. ${ }^{63}$

9. Ibn al-Bitâar (died 1248 A.C.) collected medicinal herbs by traveling in different countries. In his famous book, "al-Jāmi"", he gave systematic descriptions of 1400 medical herbs, of which 300 were new. ${ }^{\circ 4}$ It was the only book on botany and materia medica after Dioscorides (first century A.C.) up to the 16 th century. ${ }^{65}$

The above contributions are examples of some of the major contributions to the basic medical sciences during the glorious period of Muslim supremacy. In a subsequent article, the major contributions to the clinical sciences will be presented. ${ }^{2}$

It is a pity that the original manuscripts are not readily available, and that our knowledge of the subject is mostly based on the publications of oriental scholars. Direct access to the original manuscripts could reveal the real extent of the contributions of the Muslim period. However, the above short discussion should inspire Muslim scholars all over the world to undertake scientific studies with right earnest so that they may regain their lost glory.

\section{References}

1. Baas, JH: Outlines of History of Medicine and the Medical Profession, Translated by H.E. Handerson, Huntington, NY: R.E. Kreiger Publishers, 1971, p 225.

2. Muazzam, M.G, Muazzam, N: Important contribution $^{5}$ of Early Muslim period to Medical Science II Clinical Science. JIMA (In press)

3. Sarton, G: Introduction to the History of Science. Huntington, NY: R.E. Kreiger Publishers, 1975, volume 1, p574

4. Reference 3, volume 1, p559.

5. Ali, MA: Biggyaney Musalmaner Daan (in Bengali: Contributions of Muslims in Science). The Malik Library, Dhaka, Bangladesh, vol. 8, p 99.

6. Reference 1, p 228.

7. Muazzam, MG: An Introduction to Al-Rāzì and Ibn Siñā East Pak Med J 1960; 4:31.

8. Said, H: Greco-Arab Concept of Anatomy and Physiology of Heart. Hamdard Special issue, 1966; 10 (1-3), 9. (editorial)

9. Reference 1, p233.

10. Reference 5 , volume 8, p 583.

11. Aziz, MA: Ibn al-Nafis as I know him. Hamdard Karachi 1965, 9 (7-8) 3.

12. Reference 5, 8:733-34

13. Sayeed, HM: Al-Tibb al-Islami. Islamic Foundation, Dhaka, 2nd ed 1981, p43.

14. Reference $13, \mathrm{p} 44$.

15. Elgood, C: A Medical History of Persia and the Eastern Caliphate, Cambridge, 1951, p 150. 
16. Muazzam, MG: Contributions of the Arabs in the Discovery of Circulation of Blood. Ibn Sina Med Assoc J, Tripoli, Libya, 1980; 1, 27

17. Reference 8, p 9.

18. Reference 13, p 45.

19. Reference 13, p 44.

20. Reference 1, p 232.

21. Reference 1, p 232.

22. Reference 15, p 335.

23. Hitti, PK: Arab's Short History. Princeton Univ Press, 1949, p 200.

24. Ullmann, M: Islamic Surveys II, Islamic Medicine. Edin Univ Press 1978, p 69.

25. Major, R: History of Medicine, Blackwell, Oxford Publications, 1954, 1, 247

26. Haddad, SI, Khairullah, AI: Annals of Surgery, 1936; 104:1

27. Coppola, ED: The William Osler Medal Essay. Bull Hist Med 1957; 31(1), 44

28. Reference $16,1,27$

29. Rahman, SA: Research thesis on the discovery of circulation of blood. Science, Hyderabad Deccan, India 1943.

30. Reference $8, \mathrm{p} 13$.

31. Reference $16,1,29$.

32. Reference 24, p 42.

33. Reference 5, 8, 97-98.

34. Reference 5, 8, 137.

35. Reference 5, 8, 127.

36. Reference 3, 1, 609.

37. Reference 23, p 84.
38. Reference 5, 8, 149.

39. Reference $5,8,311$.

40. Reference $5,8,421$.

41. Reference $7,4,31$.

42. Reference $7,4,35$.

43. Reference 1, p 229.

44. Reference 5, 8, 477.

45. Reference $3,1,453$.

46. Reference 5, 8, 478 .

47. Reference 1, p 232.

48. Reference 1, p 232.

49. Reference 1, p 232.

50. Reference 5, 8, 575-6.

51. Reference 3, 2, 1017.

52. Reference $24, \mathrm{p} 95$.

53. Reference 5, 8, 748 .

54. Reference 15, p 281.

55. Campbell, D Arabian medicine and its influence on the Middle Ages. London: Kegan Paul, 1, 79.

56. Reference 1, p 228.

57. Reference 1, p 228.

58. Reference $5,8,326$.

59. Reference $3,1,728$.

60. Reference 3, 1, 728.

61. Reference $3,1,681$.

62. Reference 5, 8, 388 .

63. Hamarneh, SK Origins of Pharmacy and Therapy in the Near East. Tokyo. The National Foundation; 1973, 50-87.

64. Reference $55,1,101$.

65. Reference 5, 8, 619.
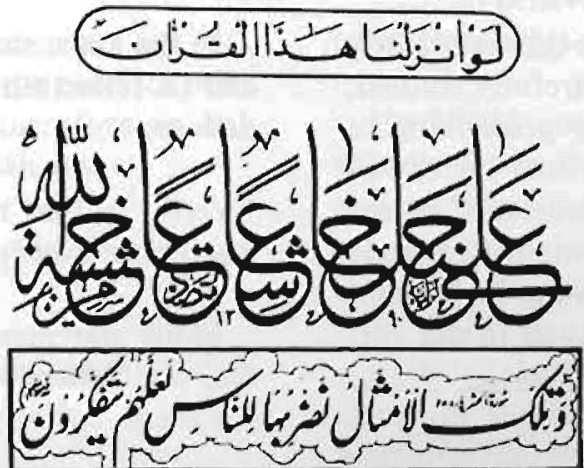